\title{
PENINGKATAN KREATIVITAS ANAK USIA 5-6 TAHUN MELALUI TEKNIK MENCETAK DENGAN MEDIA PELEPAH PISANG
}

\author{
Nursana. M. Safi' ${ }^{1}$, Bahran Taib ${ }^{2}$, Santi M. J. Wahid ${ }^{3}$ \\ Universitas Khairun Ternate \\ Fakultas Keguruan dan Ilmu Pendidikan \\ Jl. Bandarah Sultan Baabullah Kota Ternate Utara, Kotak Pos 53 Ternate 977328 \\ Telepon: (0921) 3110905-Faksimili 0921-3110901. \\ Email : nursana.safi16@gmail.com
}

\begin{abstract}
Abstrak: Dalam dunia pendidikan, kreativitas dalam diri anak dapat di tingkatkan, melalui berbagai stimulasi kegiatan yang dilakukan oleh anak. Salah satunya adalah dengan kegiatan yang dapat mengembangkan kreativitas pada anak yaitu dengan teknik mencetak menggunakan pelepah pisang. Berdasarkan penelitian kajian literatur tentang kegiatan mencetak dengan menggunakan pelepah pisang dalam meningkatkan kreativitas anak, peneliti membuat suatu kesimpulan tentang bagaimana kegiatan mencetak dengan menggunakan pelepah pisang dapat meningkatkan kreativitas anak. Pada saat anak melakukan kegiatan mencetak dengan menggunakan alat atau bahan dari pelepah pisang yang telah disediakan oleh guru dengan berbagai macam bentuk, anak akan mencoba menorehkan di atas kertas yang sudah di sediakan oleh guru. Dari hasil torehan tersebut, anak akan mempelajari bentuk dan warna yang tampak ketika anak melakukan kegiatan mencetak. Pada anak melakukan kegiatan mencetak, daya imajinasi anak akan bekerja untuk membuat sesuatu yang baru dan berbeda dari punya temannya sesuai dengan daya imajinasinya. Anak akan mulai mencoba untuk menuangkan ide-ide kreatifnya melalui mencetak menggunakan pelepah pisang dengan warna-warni cat yang dipilih oleh anak dan menorehkan diatas kertas putih. Hasil dari karya anak merupakan ungkapan imajinasinnya atau ide-ide kreatifnya sendiri. Hal ini akan dapat membuat berkembangnya kreativitas anak sejak dini.
\end{abstract}

Kata Kunci: Kreativitas, Mencetak, Pelepah Pisang

Abstract: In the world of education, creativity in children can be increased, through various stimulation activities carried out by children. One of them is by activities that can develop creativity in children, namely by printing techniques using banana fronds. Based on a literature review study of printing activities using banana fronds in increasing children's creativity, researchers make a conclusion about how printing activities using banana fronds can enhance children's creativity. When children do printing activities using tools or materials from banana fronds that have been provided by the teacher in various forms, the child will try to carve on paper that has been provided by the teacher. From the results of these incisions, children will learn the shapes and colors that appear when children do print activities. In children doing printing activities, the child's imagination will work to create something new and different from having friends in accordance with the imagination. The child will start trying to express his creative ideas through printing using banana fronds with colorful paints chosen by the child and etching them on white paper. The results of children's work are expressions of imagination or creative ideas themselves. This will be able to make the development of children's creativity from an early age.

Keywords: Creativity, Print, Banana. 


\section{A. Pendahuluan}

Pendidikan anak usia dini (PAUD) merupakan usia yang sangat penting bagi perkembangan anak sehingga disebut golden age. Anak usia dini adalah sosok individu yang sedang menjalani suatu proses perkembangan dengan pesat dan fundamental bagi kehidupan selanjutnya. Untuk mencapai perkembangan nak usia dini dengan baik, dapat dikembangkan melalui berbagai macam pelayanan pendidikan anak usia dini yang ditemukan di sekitar kita, baik yang diselenggarakan oleh pihak pemerintah maupun pihak swasta.

Dunia pendidikan sedang berusaha untuk menciptakan generasi yang kreatf agar dapat mengembangkan potensi-potensi yang ada pada diri setiap anak didik agar dapat berguna bagi diri sendiri maupun bagi orang lain. Kreativitas merupakan hal yang penting dimiliki oleh seorang individu termasuk anak. Dengan kerativitas, kehidupan seseorang akan berguna bagi nusa dan bangsa bahkan untuk dirinya sendiri. Bagi diri sendiri, kreativitas penting sebagai perwujudan diri, yang merupakan salah satu kebutuhan pokok manusia. Bagi orang lain, hasil-hasil pemikiran maupun hasil karya yang kreatif dapat berguna untuk meningkatkan taraf hidup masyarakat. Oleh sebab itu sangat diperlukan usaha pengembangan kreativitas sedini mungkin, yaitu pada masa-masa golden age.

Salah satu aspek perkembangan yang ada pada anak yang sedang berkembang salah satunya adalah aspek seni yaitu kreativitas. Kreativitas anak harus diberikan stimulasi dari mulai usia dini, sehingga anak akan mampu berpikir kreatif, karena dengan kreativitas anak akan melihat masalah dari berbagai sudut pandang, mampu menghasilkan karya yang berbeda dari yang suda ada sebelumnya. Susanto, (2011: 112) menyatakan kreativitas merupakan kemampuan umum untuk menciptakan sesuatu yang baru, baik berupa produk atau gagasan baru yang dapat diterapkan dalam memecahkan masalah, atau sebagai kemampuan untuk melihat unsur-unsur yang sudah ada. Kreativitas mulai berkembang dengan kemampuan individu untuk menciptakan sesuatu yang baru.

Supriadi, (2001) memaparkan bahwa kreativitas merupakan kemampuan seseorang untuk melahirkan sesuatu yang baru, baik berupa gagasan maupun karya nyata, yang relatif berbeda dengan apa yang telah ada sebelumnya. Sementara itu, Munandar, (1999) mengemukakan bahwa kreativitas adalah kemampuan untuk membuat kombinasi baru, berdasarkan data, informasi, atau unsur-unsur yang sudah ada atau sudah dikanal sebelumnya, yaitu semua pengalaman dan pengetahuan yang telah diperoleh seseorang selama hidupnya baik itu di lingkungan sekolah, keluarga , maupuan dari lingkungan masyarakat.

Pandangan ahli psikologi Horrace, menyatakan bahwa kreativitas adalah kemampuan seseorang untuk menemukan cara-cara baru bagi pemecahan problemaproblema, baik yang berkenaan dengan ilmu pengetahuan, seni sastra atau seni 
lainnya, yang mengandung suatu hasil atau pendekatan yang sama sekali baru bagi yang bersangkutan, meskipun bagi orang lain merupakan suatu hal yang tidak asing lagi.

Kreativitas dapat berupa kegiatan imajinatif atau sintesis pemikiran yang hasilnya bukan hanya perangkuman, mungkin mencakup pembentukan pola-pola baru dan gabungan informasi yang diperoleh dari pengalaman sebelumnya sertapencangkokan hubungan lama ke situasi baru dan mungkin mencakup pembentukan korelasi baru. Bentuk - bentuk kreativitas mungkin berupa produk seni, produk ilmiah, atau mungkin juga bersifat prosedural atau metodologis. Jadi menurut ahli ini, kreativitas merupakan aktivitas imajinatif yang hasilnya merupakan pembentukan kombinasi dari informasi yang diperoleh dari pengalaman-pengalaman sebelumnya menjadi hal yang baru, berarti dan bermanfaat.

Dari beberapa pendapat yang telah dipaparkan tersebut, dapat disimpilkan bahwa pada intinya kreativitas merupakan kkemampuan seseorang untuk menciptakan sesuatu yang baru atau merupakan hasil kombinasi dari beberapa data atau informasi yang diperoleh sebelumnya, dapat terwujud berupa gagasan atau karya nyata.

Orang yang kreatif adalah orang yang lancar menanggapi suatu masalah, mudah menyesuaikan diri, memiliki keaslian dalam berkarya, dan mampu berpikir secara integral. kreatif merupakan kemampuan berpikir tingkat tinggi yang mengimplikasikan terjadinya eskalasi dalam kemampuan berpikir, di tandai oleh suksesi, diskontinuitas, diferensiasi, dan integrasi antara setiap tahap perkembangan. Setiap orang memiliki bakat dan kreativitas, walaupun macam dan tingkat kreativitas tersebut berbeda. Dari segi pendidikan, kreativitas dalam diri anak memang dapat di tingkatkan, Melalui berbagai stimulasi kegiatan yang dilakukan oleh anak. Salah satu kegiatan yang dapat mengembangkan kreativitas anak adalah dengan teknik mencetak. Mencetak adalah salah satu karya seni. Mencetak bagi anak TK merupakan kegiatan berlatih karya seni rupa dengan menerapkan cara-cara mencetak/mencap sesuai tingkat kemampuan anak. Kreativitas mencetak dapat menggunakan bahan alam seperti mencetak dengan daun, mencetak dengan pelepah pisang, pelepah talas, pelepah papaya dan mencetak dengan umbi-umbian.

Mencetak adalah teknik membuat gambar berulang dengan menggunakan alat dan cat warna. Hasil penelitian disimpulkan bahwa: kreativitas seni rupa anak berkembang melalui kegiatan mencetak dengan bahan alam di PAUD Aisyiyah Lansano Pesisir Selatan dalam membuat gambar sederhana, dalam menciptakan gambar sederhana dan dalam merancang ulang gambar sederhana berkembang dengan pesat Supriyenti, (2013).

Dzulhulaifah, (2014) melakukan penelitian tindakan kelas dengan subjek dalam penelitian ini adalah anak kelompok B TK Negeri Pembina Cilegon yang berjumlah 9 anak. Kreativitas anak setelah dilakukan tindakan mengalami 127 Cahaya Paud 
peningkatan secara signifikan pada setiap siklus. Kemampuan anak yang dinilai dalam penelitian ini meliputi aspek Originality (keaslian), Fleksibility (keluwesan), Fluency (kelancaran), dan Elaborasi (penguraian). Kesimpulan penelitian ini adalah bahwa bahan alam dapat dijadikan sebagai salah satu media pembelajaran di TK, karena selain meningkatkan kreativitas anak, juga menambah pengetahuan anak terhadap bahan alam di lingkungan sekitar.

Agustiningsih (2018) melakukan penelitian dan dari hasil perbaikan pembelajaran telah dapat dilaksanakan dan ditarik simpulan sebagai berikut: a) Dengan memberikan latihan dan kegiatan mencetak dengan berbagai media dan sesuai dengan indikator maka anak telah mengembangkan kemampuan seninya, sehingga anak menjadi lebih kreatif dan aktif. Dengan kegiatan mencetak dapat dapat meningkatkan kemampuan dasar seni anak pada kelompok B, b) Peningkatan kemampuan seni pada anak meningkat secara konsisten. Pada siklus I terdapat peningkatan sebesar $18,75 \%$, Peningkatan pada siklus II sebesar 37,5\%. Peningkatan tersebut berdasarkan jumlah siswa yang mendapat jumlah bintang 4. Sagala (2019) juga melakukan penelitian pada anak kelompok B di TK Assisi Medan T.A 2018/2019, dengan sampel 19 anak. Hasil pengujian hipotesis menunjukkan ada perbedaan yang signifikan mengenai kreativitas anak di kelas yang melakukan kegiatan mencetak dengan anak di kelas yang melakukan kegiatan mewarnai dengan Zhitung= $-4,6$ Ztabel $=1,96$. Sehingga dapat ditarik kesimpulan ada perbedaan yang signifikan dalam meningkatkan kreativitas anak kelompok B antara kelas yang diberikan perlakuan mencetak dan kelas yang diberi perlakuan kegiatan mewarnai.

Fauziani (2017) Berdasarkan hasil observasi awalnya, kondisi kreativitas anak rendah, karya yang anak hasilkan tidak beragam. Anak tidak bisa mengembangkan imajinasinya. peneliti memberikan tindakan melalui kegiatan mencetak agar kegiatan di kelas menjadi lebih menyenangkan bagi anak. Metode yang digunakan dalam penelitian ini adalah metode penelitian tindakan yang terdiri dari 2 siklus. Masingmasing siklus terdiri dari beberapa tahap yaitu perencanaan, tindakan dan pengamatan serta refleksi.Pada siklus I diberikan sebanyak 8 kali tindakan dan pada siklus II pertemuan 2 penelitian sudah dinyatakan berhasil dengan kriteria keberhasilan kreativitas mencapai 70\%. Subjek pada penelitian ini adalah anak usia 56 tahun yang berada di BKB Kemas IQRO Serang-Banten yang terdiri dari 2 anak lakilaki dan 8 anak perempuan. Teknik pengumpulan data melalui catatan lapangan, observasi, catatan wawancara dan dokumentasi. Sebelum tindakan, hasil observasi menunjukkan persentase sebesar 27\%. Pada siklus I, kreativitas anak meningkat sebesar 57\%, hal ini menunjukkan adanya peningkatan sebesar 30\% dari pra tindakan ke siklus I. Dari siklus II, perkembangan anak mengalami peningkatan yang signifikan mencapai 87\%. dengan kata lain, kreativitas anak dapat ditingkatkan melalui kegiatan mencetak menggunakan bahan alam.

Bahan alam disekitar kita dapat digunakan sebagai media dalam kegiatan pembelajaran. Berdasarkan kajian pada beberapa leteratur terlihat bahwa kegiatan 
mencetak dengan berbagai bahan dapat membantu anak menjadi kreatif. Kreativitas anak dapat berkembang lebih baik dengan kegiatan mencetak yakni anak dapat membuat bentuk-bentuk sesuai dengan hasil imajinasinya. Dalam penelitian kajian pustaka ini peneliti ingin mengkaji tentang bagaimanakah pelepah pisang dapat digunakan anak sebagai alat mencetak guna menuangkan ide-ide kreatifnya dalam suatu kegiatan mencetak di lembaga pendidikan anak usia dini (PAUD).

\section{B. Pembahasan}

Kreativitas merupakan salah satu potensi yang dimiliki anak yang perlu dikembangkan sejak usia dini. Setiap anak memiliki bakat kreatif dan ditinjau dari segi pendidikan, bakat kreatif dapat dikembangkan dan perlu dipupuk sejak dini. Bila bakat kreatif anak tidak dipupuk maka bakat tersebut tidak akan berkembang, bahkan menjadi bakat yang terpendam yang tidak dapat diwujudkan.

Salah satu usaha yang dilalukan guru untuk mengembangkan kreativitas anak dengan kegiatan mencetak. Dengan melakukan kegiatan mencetak ini dapat mengembangkan kreativitas anak. Adapun kelebihan-kelebihan dari kegiatan mencetak diantaranya: Anak lebih sabar dan kreatif dalam menyelesaikan kegiatan mencetak, anak lebih teliti membuat bentuk dari alat cetak, anak lebih kreatif mengenal warna-warna, dan anak lebih kreatif menjawab pertanyaan-pertanyaan dari guru. Adapun langkah-langkah kegiatan mencetak adalah menyediakan alat dan bahan untuk mencetak seperti: pelepah pisang, daun, dan wortel. Selanjutnya menyediakan bantalan stempel dan kemudian diberi pewarna, kemudian anak mencapkan salah satu alat mencetak misalnya pelepah pisang ke pewarna kemudian cap kan pelepah pisang ke atas kertas, selanjutnya anak mencapkan pelepah pisang pada pewarna kemudian di cap kan ke atas kertas secara sampai membentuk gambar.

Kreativitas anak juga dapat dikembangkan dengan kegiatan mewarnai gambar. Kegiatan mewarnai merupakan kegiatan yang menyenangkan untuk anak. Menyenangkan yang dimaksud di sini terletak pada proses memilih warna yang digunakan untuk mewarnai bidang gambar kosong. Mewarnai pada anak usia dini bertujuan untuk melatih keterampilan, kerapian serta kesabaran". Kerapian dilihat dari bagaimana anak memberi warna pada tempat-tempat yang telah ditentukan semakin lama anak akan semakin terampil untuk menggoreskan media pewarnanya karena sudah terbiasa. Adapun langkah-langkah kegiatan mewarnai gambar yaitu, menyediakan gambar, menyediakan pensil warna, kemudian anak mewarnai gambar sesuai kemampuan anak.

\section{Kajian Teori}

Pada anak-anak kreativitas sedang menonjol perkembangannya, dengan dorongan bermain dan keinginan hendak tahu yang membludak, hingga mudah tercapai penghayatan. Tuhan memberikan anugerah pada anak, hingga baginya bermain adalah pula belajar, bereksperimen, berekspresi dan berkreasi: Belajar sambli bermain, bermain sambil belajar (Tabrani, 2001). Kreativitas anak usia dini 
adalah kreativitas alamiah yang dibawa dari sejak lahir dan merupakan kemampuan untuk menghasilkan pemikiran-pemikiran yang asli, tidak biasa, dan sangat fleksibel dalam merespon dan mengembangkan pemikiran dan aktivitas. Kreativitas alami seorang anak usia dini terlihat dari rasa ingin tahunya yang besar. Hal ini terlihat dari banyaknya pertanyaan yang diajukan kepada orang tuanya terhadap sesuatu yang dilihatnya. Adakalanya pertanyaan itu diulang-ulang dan tidak ada habis-habisnya. Selain itu, anak juga senang mengutak-atik alat mainannya sehingga tidak awet dan cepat rusak hanya karena rasa ingin tahu terhadap proses kejadian. Kreativitas anak dapat dikembangan dengan cara bermain, dalam penelitian ini akan diambil salah satu bentuk permainan yang dapat menigkatkan kreativitas seni rupa anak yaitu kegiatan mencetak dengan bahan alam (Supriyenti, 2013).

Kreativitas merupakan suatu kondisi, sikap atau keadaan yang sangat khusus sifatnya dan hampir tidak mungkin dirumuskan secara tuntas. Kreativitas dapat didefinisikan dalam beranekaragam pernyataan tergantung siapa dan bagaimana menyorotinya. Istilah kreativitas dalam kehidupan sehari-hari selalu dikaitkan dengan prestasi yang istimewa dalam menciptakan sesuatu yang baru, menemukan cara-cara pemecahan masalah yang tidak dapat ditemukan oleh kebanyakan orang, ide-ide baru, dan melihat adanya berbagai kemungkinan (Turyani dan Wondal, 2018).

Semiawan (2009) mengungkapkan bahwa kreativitas adalah modifikasi sesuatu yang sudah ada menjadi konsep baru. Dengan kata lain, terdapat dua konsep lama yang dikombinasikan menjadi suatu konsep baru. Ia menjelaskan bahwa ciri-ciri kreativitas adalah:

1. Berani mengambil resiko,

2. Memainkan peran yang positif berfikir kreatif,

3. Merumuskan dan mendefinisikan masalah,

4. Tumbuh kembang mengatasi masalah,

5. Toleransi terhadap masalah ganda (ambigutiy),

6. Menghargai sesama dan lingkungan sekitar.

Susanto mengatakan bahwa kreativitas perlu dikembangkan sejak dini. Kreativitas merupakan kemampuan umum untuk menciptakan sesuatu yang baru baik berupa produk atau gagasan baru yang dapat diterapkan dalammemecahkan masalah, atau sebagai kemampuan untuk melihat unsur-unsur yang sudah ada sebelurnnya. Pengembangan kreativitas sangat penting, karena dengan berkreativitas seseorang dapat mewujudkan atau mengaktualisasikan dirinya yang merupakan kebutuhan pokok tertinggi dalam hidup manusia (Riski, 2016).

Sumanto (2005: 38) mengemukakan aspek yang terkandung di dalam kreativitas adalah:

1. Kelancaran menanggapi suatu masalah, ide, dan materi,

2. Mudah menyesuaikan diri terhadap setiap situasi, 
3. Memiliki keaslian dalam membuat tanggapan, karya yang lain daripada yang lainnya, dan

4. Mampu berpikir secara integral, mampu menghubungkan satu dengan yang lain.

Jamaris (2006: 67) juga mengungkapkan bahwa aspek kreativitas meliputi:

1. Kelancaran, yaitu kemampuan untuk memberikan jawaban dan mengemukakan gagasan atau ide-ide yang ada dalam pikiran anak dengan lancar.

2. Kelenturan, yaitu kemampuan untuk mengemukakan berbagai alternatif dalam pemecahan masalah

3. Keaslian, yaitu kemampuan untuk menghasilkan berbagai ide atau karya yang asli hasil pemikiran sendiri.

4. Elaborasi, yaitu kemampuan untuk memperluas ide dan aspek-aspek yang mungkin tidak terpikirkan atau terlihat oleh orang lain

5. Keuletan dan kesabaran, yaitu keuletan dalam menghadapi rintangan, dan kesabaran dalam menghadapi suatu situasi yang tidak menentu.

Suratno (2005: 39) mengemukakan bahwa bakat kreatif akan tumbuh dan ber kembang jika didukung dengan fasilitas dan kesempatan yang memungkinkan. Dengan adanya keragaman bakat dan kreativitas anak, orang tua dan guru harus menyadari akan hal itu. Adapun metode yang dapat mengembangkan bakat dan kreativitas anak, antara lain:

1. Pribadi

Kreativitas merupakan keunikan individu dalam berinteraksi dengan lingk ungannya. Masing-masing anak mempunyai bakat dan kecepatan serta kreativitas yang berbeda, oleh sebab itu orang tua dan guru TK dapat menghargai keunikan pribadi masing-masing. Agar bakat dan kreativitas pribadi anak dapat tumbuh dan berkembang, maka orang tua dan guru TK serta lingkungan hendaknya membantu anak untuk menemukan bakat dan kreativitasnya. Hal ini dilakukan dengan cara memberikan kebebasan yang cukup serta memfasilitasi mereka secara memadai pula.

2. Pres atau pendorong

Kreativitas dapat diwujudkan jika didukung oleh lingkungan dan kemauan dari dalam dirinya yang kuat. Ada dua faktor yang mendukung kemauan seseorang yaitu motivasi intrinsik (kesadaran diri) dan motivasi ekstrinsik (penghargaan atas kreasi yang dihasilkan anak, pujian, dan insentif atau hadiah atas keberhasilan).

Keberhasilan peningkatan perkembangan kreativitas melalui kegiatan mencetak dengan media bahan alam yang ditandai dalam lembar observasi yaitu anak mengikuti kegiatan dengan antusias dan aktif sehingga pembelajaran menjadi lebih menyenangkan dan memberikan pengalaman yang baru bagi anak, anak mampu menciptakan bentuk yang bervariasi, anak mencoba lebih dari satu kegiatan, anak dapat bereksplorasi dengan berbagai media yang telah disediakan, anak tidak lagi meniru hasil karya teman, anak dapat mengkomunikasikan hasil karyanya di depan guru dan teman, anak mau membantu teman yang sedang kesulitan dan anak memiliki 131 Cahaya Paud 
kepekaan terhadap lingkungan, hal ini membuat anak membantu temannya yang sedang kesulitan dalam kegiatan pembelajaran (Fauziani and Fatima, 2017).

Berukut ini adalah table ciri-ciri anak kreatif berdasarkan perbedaan tingkat kreativitas (tinggi dan rendah) menurut Turyani dan Wonda,l (2018):

Tabel 1. Ciri-ciri Anak Yang Memiliki Tingkat Kreativitas Yang Tinggi Dan Rendah

\begin{tabular}{|c|c|}
\hline \multicolumn{2}{|c|}{ Ciri-ciri Tingkat Kreativitas Anak } \\
\hline Tingkat Kreativitas Tinggi & Tingkat Kreativitas Rendah \\
\hline $\begin{array}{l}\text { 1. Imajinatif } \\
\text { 2. Mempunyai prakarsa } \\
\text { 3. Mempunyai minat luas } \\
\text { 4. Mandiri dalam berpikir } \\
\text { 5. Melit (selalu ingin tahu segalanya) } \\
\text { 6. Senang berpetualang } \\
\text { 7. Penuh energi } \\
\text { 8. Percaya diri } \\
\text { 9. Bersedia mengambil resiko } \\
\text { 10. Berani dalam pendirian dan } \\
\text { keyakinan. }\end{array}$ & $\begin{array}{l}\text { 1. Kurang suka berimajinatif } \\
\text { 2. Kadang tidak mempunyai prakarsa } \\
\text { 3. Memiliki minat yang terbatas } \\
\text { 4. Tergantung pada ide-ide orang lain } \\
\text { 5. Merasa puas dengan apa yang sudah } \\
\text { diketahui } \\
\text { 6. Bersikap tertutup } \\
\text { 7. Cepat menyerah } \\
\text { 8. Tidak percaya diri } \\
\text { 9. Tidak berani mengambil resiko } \\
\text { 10. Tidak berpendirian, mudah dipengaruhi }\end{array}$ \\
\hline
\end{tabular}

1. Aspek Kreativitas

Terdapat beberapa aspek yang terkandungdi dalam kreativitas itu sendiri. Aspek-aspek inilah yang dapat dikembangkan pada kreativitas untuk anak. Berikut ini dipaparkan oleh beberapa ahli tentang aspek-aspek yang terkandung di dalam kreativitas. Pernes (Narsito, dikutip dalam Euis Kurniati \& Yeni Rachmawati, 2010:

14) mengemukakan beberapa aspek kreativitas:

a. Fluency (Kelancaran), yaitu kemampuan mengemukakan ide yang serupa untuk memecahkan suatu masalah.

b. Flexlibility (keluwesan), yaitu kemampuan untuk menghasilkan berbagai macam ide guna memecahkan suatu masalah di luar kategori yang biasa.

c. Originality (Keaslian), yaitu kemampuan memberikan respons, yang unik atau luar biasa.

d. Elaboration (keterperincian), yaitu kemampuan menyatakan pengarahan ide secara terperinci untuk mewujudkan ide menjadi kenyataan.

e. Sensitivity (kepekaan), yaitu kepekaan menangkap dan menghasilkan masalah sebagai tanggapan terhadap suatu situasi.

Sumanto , (2005: 38) juga mengemukakan aspek yang terkandung didalam kreativitas adalah (a) kelancaran menanggapi suatu masalah, ide, dan materi, (b) mudah menyesuaikan diri terhadap setiap situasi, (c) memiliki keaslian dalam membuat tanggapan, karya yang lain dari pada yang lainnya, dan (d) mampu berpikir secara integral, mampu menghubungkan satu dengan yang lain. 
Sedangkan menurut Martini Jamaris, (2006:67) aspek kreativitas meliputi:

a. Kelancaran, yaitu kemampuan untuk memberikan jawaban dan mengemukakan gagasan atau ide-ide yang ada dalam pikiran anak dengan lancer.

b. Kelenturan, yaitu kemampuan untuk mengemukakan berbagai alternative dalam pemecahan masalah.

c. Keaslian, yaitu kemampuan untuk menghasilkan berbagai ide atau karya yang asli hasil pemikiran sendiri.

d. Keuletan dan kesabaran, yaitu keuletan dalam menghadapi rintangan, dan kesabaran dalam menghadapi suatu situasi yang tidak menentu.

Dari ketiga pemaparan di atas ditemukan bahwa adanya kesamaan aspek yang terkandung dalam kreativitas yaitu terdapat kelancaran (fluency) berkaitan dengan kemampuan anak untuk mengemukakan ide, gagasan, dan materi yang ada di dalam pikiran anak untuk memecahkan suatu masalah dengan lancar, kelenturan (flexibility) yaitu kemampuan anak dalam menghasilakn berbagai macam ide sebagai alternative dalam memecahkan masalah, dan mudah menyesuaikan diri, keaslian (originality) yaitu kemampuan anak dalam menghasilkan berbagai ide atau hasil karya asli dari hasil pemikirannya sendiri , anak juga mampu memberikan respons yang unik dan luar biasa, dan keterperincian (elaboration) yaitu kemampuan dalam menyatakan ide secara lebih rinci untuk memerlukan ide dan aspek -aspek yang mungkin tidak terpikirakan oleh orang lain kemudian mewujudkan ide tersebut menjadi nyata dalam sebuah karya atau hasil.

Dengan pemikiran yang luwes (fleksibel) orang kreatif dapat mengutakatik sesuatu dan mencoba berbagai kemungkinan yang bisa dilakukan. Dengan memiliki cara berpikir luwes, orang kreatif tidak terikat pada informasi-informasi yang sudah ada, sehingga melalui pemikirannya yang luwes dapat menciptakan suatu hal yang bersifat baru dan unik.

2. Kegiatan Mencetak

Mencetak merupakan kegiatan seni rupa yang termasuk seni dua dimensi. Sebenarnya kegiatan mencetak ini tidak asing bagi anak-anak. Mereka sering melakukannya di atas trotoar atau dinding dengan menjejakkan alas sepatu atau tangannya ke atas trotoaran dinding tersebut. Kadang-kadang mereka menjejakkan kakinya di atas lumpur atau pasir pantai hingga terdapat bekas jejakjejak kaki tersebut. Kreasi lain sering juga dilakukan dengan membuat goresan dari tongkat ke atas pasir laut, atau tanah. Tanpa disadari kegiatan tersebuat merupakan kegiatan mendesain yang dilakukan berulang-ulang yang merupakan kegiatan mencetak (Soegiarty, 2007). 
Mencetak atau seni grafis atau grafika adalah seni rupa yang cetakannya dikerjakan dengan tangan. Mencetak merupakan suatu cara memperbanyak gambar dengan alat cetak atau acuan yang disebut klise. Berdasarkan jenis klisenya (cetakan) dan mencetak (seni grafis) meliputi berikut. Proses mencetak diawali dengan pembuatan klise atau acuan cetak. Klise atau acuan cetak dapat terbuat dari bahan kayu atau papan, karet, logam, atau bahan lain. Klise diolesi dengan tinta cetak, lalu diletakkan pada selembar kertas ditekan-tekan hingga rata,tinta dari klise melekat pada kertas, dan jadilah hasil karya cetak atau seni grafika (Nurani ,2009).

Prinsip kerja dalam mencetak adalah tersedianya acuan yang dipakai sebagai master yang dipergunakan sebagai klise yang dapat menghasilkan hasil cetakan. Acuan ini terdiri dari cetak tinggi, cetak datar, cetak dalam, cetak tembus/saring. Acuan diberi warna kemudian dicapkan atau dicetakkan pada bidang datar secara berulang-ulang sejumlah yang diinginkan (Agustiningsih, 2018).

Terdapat beberapa teknik yang dapat digunakan untuk mencetak, berdasarkan proses pembuatannya menjelaskan beberapa teknik, yaitu:

a. Cetak tinggi adalah teknik mencetak dengan menggunakan alat cetak yang permukaannya tinggi atau berbentuk relief, ketika diatas acuan (alat mencetak) diberi tinta/cat kemudian dicapkan pada bahan yang dipakai mencetak (misalnya kertas gambar) maka akan dihasilkan bentuk cap yang sama dengan bentuk acuannya;

b. Cetak datar adalah teknik mencetak dengan menggunakan alat cetak yang permukaannya rata/datar, artinya tidak membentuk gambar timbul, tidak berlubang dan tidak membentuk goresan alur rendah. Disebut sebagai cetak tunggal karena teknik ini hanya dapat menghasilkan satu karya cetak saja. Artinya acuannya hanya bisa dipakai satu kali mencetak saja, tidak bisa dipakai berulang-ulang seperti halnya cetak lainnya;

c. Cetak dalam atau cetak rendah adalah teknik mencetak menggunakan alat cetak yang permukaannya rendah, yaitu berupa alur rendah/dalam bekas torehan alat yang digunakan. Selanjutnya pada acuan yang rendah tersebut diberi cat/tinta dan kemudian dicapkan ke bahan yang dipakai mencetak maka akan pindahlah cat/tinta tersebut dan akan menghasilkan bentuk cetakan tertentu;

d. Cetak sablon adalah teknik mencetak dengan menggunakan acuan cetak yang berlubang-lubang atau membentuk saringan tembus sehingga tinta cetak akan meresap/bentuk melalui lubang-lubang acuan ke bahan yang dipakai mencetak. Cetak stensil adalah salah satu contoh cetak sablon (Sumanto 2005).

Kamaril, (2002: 4.45-4.53) mengungkapkan bahwa proses mencetak yaitu membuat acuan atau klise dengan cara menggores atau mencukil pada sekeping papan, gips, logam, atau bahan lainnya. Hasil cukilan diolesi tinta, kemudian 
dilekatkan pada selembar kertas dan ditekan. Akhirnya tinta dari acuan melekat pada kertas.

Cara mencetak dengan pelepah pisang bagi anak dengan pengawasan orang dewasa atau guru, sebagai berikut: Bahan dan alat yang diperlukan: kertas, pewarna, pelepah daun, pisau, cutter, silet, alas pewarna, spon/busa, kapas, koran bekas. Proses pengerjaannya:

a. Pilihlah penampang apa yang akan dijadikan acuan cetaknya pelepah pisang.

b. Potonglah pelepah pisang dengan pisau, cutter atau silet. Arah potongan bebas. Usahakan agar permukaan potongan rata. Kerataan permukaan potongan sangat menentukan hasil cetakannya.

c. Siapkan pewarna. Pewarna yang disiapkan bergantung dari keadaan bahan acuan cetaknya. Bila acuan cetaknya masih mengeluarkan getah/cairan, cukup disediakan serbuk pewarna saja. Pewarna akan menjadi cair setelah bersatu dengan cairan acuan cetak. Akan tetapi bila acuan cetaknya tidak mengeluarkan cairan, kita perlu menyediakan pewarna yang sudah dicampur dengan air.Pewarna serbuk, cukup disebarkan pada alas warna yang bentuknya datar dan rata misalnya: kaca, formica, lembaran plastik, piring. Penampang acuan cetak yang mengandung cairan digosok-gosokan pada serbuk warna yang ditaburkan di alas hingga rata, maka terjadilah warna yang siap pakai. Pewarna cair dapat dipulaskan pada busa/spon, atau pada kapas.

d. Mencetakkan acuan cetak. Untuk mendapatkan hasil yang memuaskan ikutilah petunjuk ini.

1) Penampang acuan cetak yang masih basah tekankan pada pewarna yang ada pada alas warna tadi.

2) Selanjutnya tempelkan (sambil ditekan) acuan cetak tersebut pada kertas yang sudah diletakkan di atas koran.

3) Kemudian angkat acuan cetaknya. Gambar acuan cetak akan tertera pada kertas. Untuk membuat bentuk/gambar yang sama, lakukan kegiatan seperti yang dilakukan sebelumnya beberapa kali bergantung kebutuhan pada kertas yang sama atau yang lain.

4) Acuan cetak yang sudah kering (tidak mengeluarkan cairan), pengisian warnanya harus dengan cara menempelkan acuan cetak tersebut pada spon/busa, atau kapas yang sudah diisi pewarna. Pencetakannya sama seperti pada pencetakkan acauan cetak sebelumnya. Demikian pula pengulangan pencetakkannya.

5) Perlu diperhatikan agar pewarna yang menempel pada acuan cetak tidak berlebihan, tidak pula kekurangan. Bila hal ini terjadi, hasil cetakannya tidak akan memuaskan. 
Berikut adalah gambar proses kerja mencetak dengan pelepah pisang:

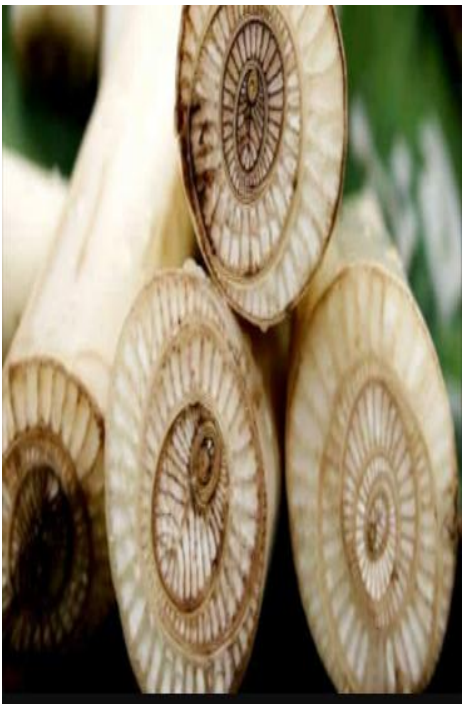

Gambar 1. Pelepah Pisang Sumber:https://www.deher ba.com/wpcontent/uploads/2019/08/ Pelepah-Pisang-2.jpg

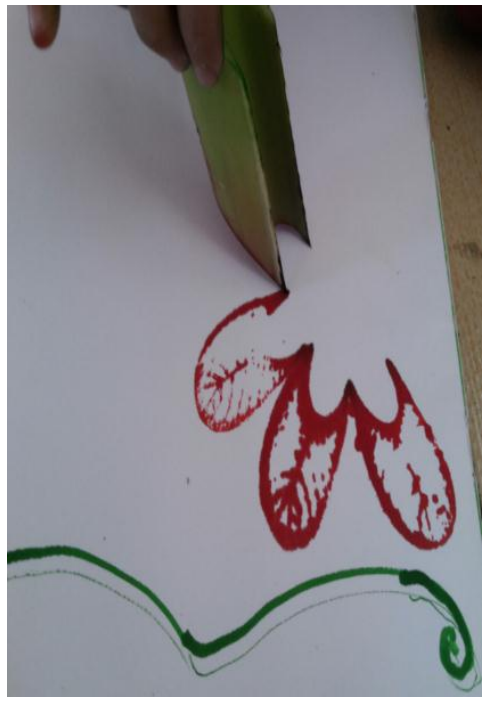

Gambar 2. Proses Mencetak Sumber:https://ummualiyyah. files.wordpress.com/2015/11 /20151112 1055441.jpg

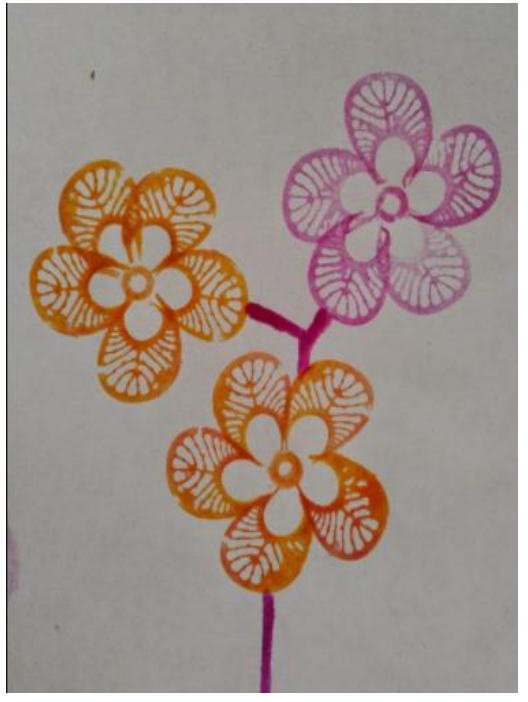

Gambar 3. Hasil Mencetak

Sumber:https://4.bp.blogspot.co m/Da9p5vdJkI/U51K_by07PI/AA AAAAAACwY/7T4jzp-WNM/s1600/1.jpg

Berikut adalah gambar proses kerja mencetak dengan pelepah pisang:

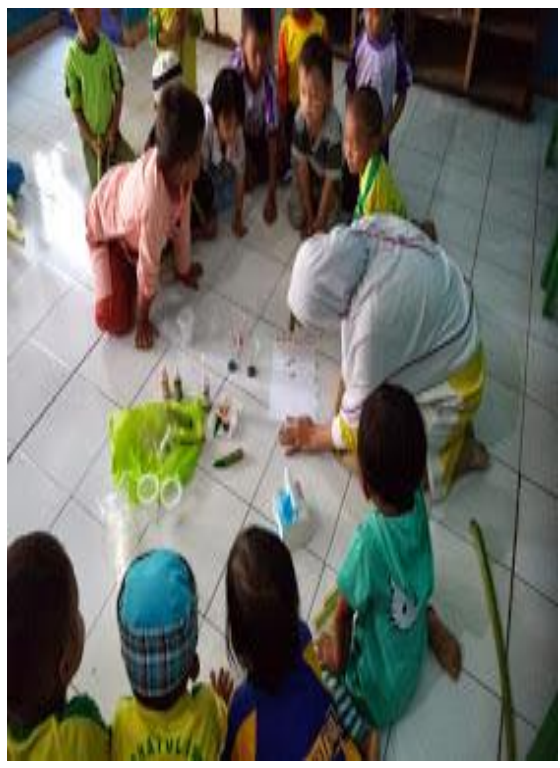

Gambar 4. Penyiapan Alat dan Bahan

Sumber: http://paud raudhatulirf an. blogspot.com /2013/10/kreat ivitas-mencap-dengan- Pelepahpisang.html?m=1.jpg

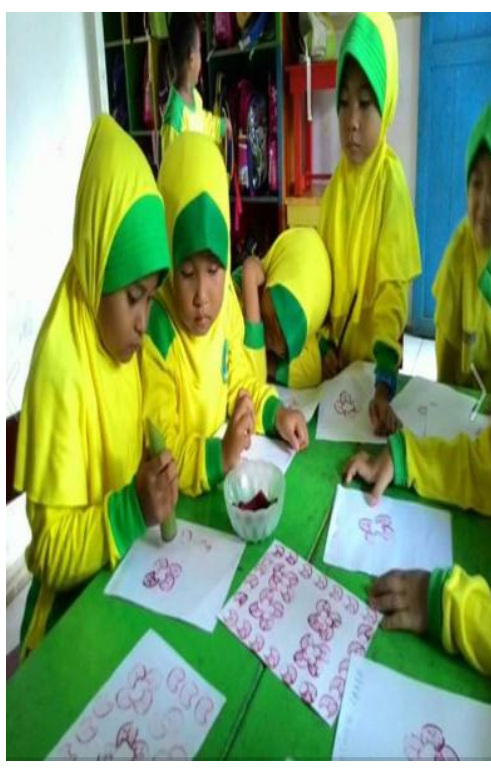

Gambar 5. Proses Mencetak

Sumber: http://paud raudhat ulirfan. blogspot.com /2013/ $10 /$ kreativitas-mencapdengan- Pelepahpisang.html?m=2.jpg

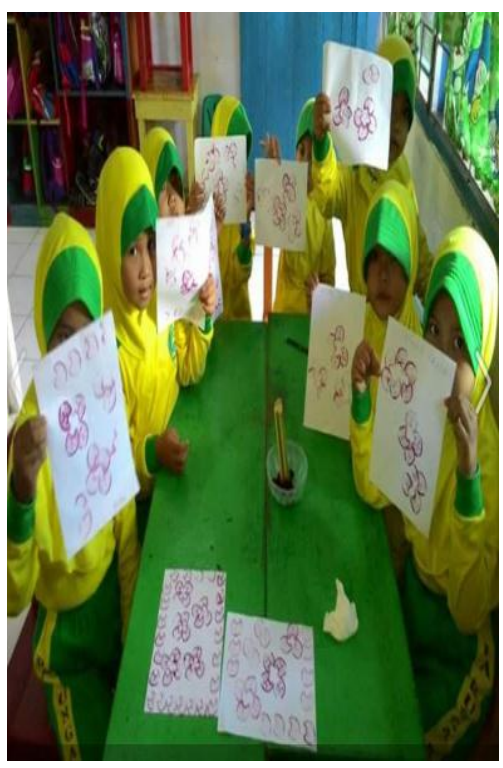

Ganbar 6.Hasil Mencatak

Sumber: http://paud raudh atulirfan. blogspot.com /20 $13 / 10 /$ kreativitas-mencapdengan- Pelepahpisang.html?m=3.jpg 


\section{Simpulan}

Berdasarkan kajian literatur tentang kegiatan mencetak dengan menggunakan pelepah pisang dalam meningkatkan kerativitas anak, peneliti membuat suatu kesimpulan tentang bagaimana kegiatan mencetak dengan menggunakan pelepah pisang dapat meningkatkan kreativitas anak. Pada saat anak melakukan kegiatan mencetak dengan menggunakan alat atau bahan dari pelepah pisang yang telah di sediakan oleh guru dengan berbagai macam bentuk, anak akan mencoba menorehkan di atas kertas yang sudah di sediakan oleh guru. Dari hasil torehan tersebut, anak akan mempelajari bentuk dan warna yang tampak ketika anak melakukan kegiatan mencetak. Pada anak melakukan kegiatan mencetak, daya imajinasi anak akan bekerja untuk membuat sesuatu yang baru dan berbeda dari punya temannya sesuai dengan daya imajinasinya. Anak akan mulai mencoba untuk menuangkan ide-ide kreatifnya melalui mencetak menggunakan pelepah pisang dengan warna-warni cat yang dipilih oleh anak dan menorehkan diatas kertas putih. Hasil dari karya anak merupakan ungkapan imajinasinnya atau ide-ide kreatifnya sendiri. Hal ini akan dapat membuat berkembangnya kreativitas anak sejak dini.

\section{DAFTAR PUSTAKA}

Agustiningsih Tiwuk, (2018). Efektivitas Kegiatan Mencetak dengan Berbagai Media dalam Meningkatkan Kemampuan Dasar Seni Anak pada Kelompok B di TK Yos Sudarso. JURNAL PENDIDIKAN: Riset \& Konseptual E-ISSN: 2598-2877 http://journal. unublitar.ac.id/ pendidikan/index.php/Riset_Konseptual P-ISSN: 2598-5175 Vol. 2 No. 4, Oktober 2018

Dzulhulaifah, (2014). Meningkatkan Kreativitas Anak Melalui Teknik Mencetak Dengan Pelepah Pisang. Universitas Pendidikan Indonesia. repository.upi.edu. perpustakaan.upi.edu,http://repository.upi.edu/15484/6/S_PAUD0902939 Abstract. pdf diungah 5 juli 2020

Fauziani Nabila, (2017). Kreativitas Anak Melalui Kegiatan Mencetak Dengan Bahan Alam. Jurnal Penelitian Dan Pengembangan Pendidikan Anak Usia Dini (JPPPAUD FKIP UNTIRTA) Volume 4 Nomor 2, November 2017

Kamaril, Cut. (2002). Pendidikan Seni Rupa/ Kerajinan Tangan. Jakarta: Universitas Terbuka.

Martini Jamaris. (2006). Perkembangan dan Pengembangan Anak Usia Taman Kanakkanak. Jakarta: Grasindo.

Nurani, Yuliani. (2009). Konsep Dasar Pendidikan Anak Usia Dini. Jakarta: PT Indeks. 
Riski Finna Kurnia, (2016). Meningkatkan Kreativitas Menciptakan Berbagai Bentuk Dengan Menggunakan Media Playdough pada anak Kelompok A. Jurnal PAUD Teratai Volume 05 November 02Tahun 2016, 1-4,

Supriyenti, Adi. (2013). "Meningkatkan Kreativitas Seni Rupa Anak Melalui Kegiatan Mencetak Dengan Bahan Alam Di PAUD Aisyiyah Lansano Pesisir Selatan." Spektrum: Jurnal Pendidikan Luar Sekolah (PLS) 1(2):15-34

Supriyenti Adi 2013. Meningkatkan Kreativitas Seni Rupa Anak Melalui Kegiatan Mencetak Dengan Bahan Alam Di Paud Aisyiyah Lansano Pesisir Selatan, SPEKTRUM PLS Vol. I, No.2, Juli 2013

Soegiarty Tity, 2007. Mencetak bagi anak usia dini. Kabupaten sumedang 2007 http://file.upi.edu/Direktori/FPSD/JUR__PEND._SENI_RUPA/195509131985032TITY_SOEGIARTY/Mencetak_Bagi_Anak_Usia_Dini.pdf

Semiawan Conny R. (2009). Memupuk Bakat dan Kreativitas Siswa Sekolah Menegah. Jakarta: Gramedia.

Sumanto. (2005). Pengembangan Kreativitas Seni Rupa Anak TK. Jakarta: Departemen Pendidikan Nasional Direktorat Jenderal Pendidikan Tinggi, Direktorat Pendidikan Tenaga Kependidikan dan Ketenagaan Perguruan Tinggi.

Sagala Remida , Kamtini, (2019). Pengaruh Kegiatan Mencetak Terhadap Kreativitas Anak Kelompok B Di TK Assisi Medan Tahun ajaran 2018/2019, Jurnal Usia Dini E-ISSN: : 2502-7239 Volume 5 No.2 Desember 2019 P-ISSN: 2301-914X 29

Turyani Sri Mayrawati Eka dan Rosita Wondal, (2018), Pengembangan Kreativitas Pembelajaran pada Anak Usia Dini, Pedoman Pembelajaran Bagi Pendidik, Praktisi Pendidikan Dan Orang Tua, Yogyakarta: Chivita Books

Munandar, Utami. 2014. Pengembangan Kreativitas Anak Berbakat. Jakarta: Rineka Cipta.

Suratno. 2005. Pengembangan Kreativitas Anak Usia Dini. Uakarta: Departemen Pendidikan Nasional, Direktorat Jenderal Pendidikan Tinggi, Direktorat Pendidikan Tenaga Kependidikan dan Ketenagaan Perguruan Tinggi).

Tabrani, Permadi. (2001). Memahami Cara Berpikir dan Bahasa Rupa Anak, dalam Wacana Seni Rupa Vol. 2, 1, Maret 2001. Bandung: STISI

https://www.deherba.com/wp-content/uploads/2019/08/Pelepah-Pisang-2.jpg

https://ummualiyyah.files.wordpress.com/2015/11/20151112_1055441.jpg

138 Cahaya Paud 
Nursana. M. Safi, Bahran Taib, Santi M. J. Wahid

http://paud raudhatulirfan. blogspot.com /2013/10/kreativitas-mencap-dengan- Pelepahpisang.html?m=1.jpg 